A Journal of Culture, English Language, Teaching \& Literature ISSN 1414-3320 (Print), ISSN 2502-4914 (Online)

Vol. 18 No.2; December 2018

Copyright $\odot$ Soegijapranata Catholic University, Indonesia

Beyond Essay Structure: Competence and Literacy

${ }^{1}$ Mister Gidion Maru, ${ }^{2}$ Ekawati Marhaenny Dukut, and ${ }^{3}$ Nihta Liando

${ }^{1,3}$ English Department Faculty of Languages and Arts, Universitas Negeri Manado, Indonesia

${ }^{2}$ English Department Faculty of Language and Arts, Soegijapranata Catholic University, Semarang, Indonesia email: ${ }^{1}$ mrhekang@yahoo.com; ${ }^{2}$ ekawati@unika.ac.id; 3nihtaliando@unima.ac.id 


\title{
Beyond Essay Structure: Competence and Literacy
}

\author{
${ }^{1}$ Mister Gidion Maru, ${ }^{2}$ Ekawati Marhaenny Dukut, and \\ ${ }^{3}$ Nihta Liando
}

1'mrhekang@yahoo.com; 2ekawati@unika.ac.id;

${ }^{3}$ nihtaliando@unima.ac.id

${ }^{1,3}$ English Department Faculty of Languages and Arts, Universitas Negeri Manado, Indonesia

${ }^{2}$ English Department Faculty of Language and Arts, Soegijapranata Catholic University, Semarang, Indonesia

\begin{abstract}
This paper intends to share the making of the students' competence and literacy awareness in the teaching of essay writing using jeremiad approach, which is so-called T-Ex, approach in EFL class. The approach suggests three aspects namely text explanation which prescribes the identification and presentation of a certain challenging issue. It is followed by the step of text examination that underlines the presence of possible solution toward the issue by referring to related knowledge and technology, socio-cultural values, and outstanding figures. It is concluded by the text expectation that proposes the hope of recalling the acquired knowledge and sharing it for future anticipation. All of the steps rely upon the language competence since they use language as a media of constructing and recognizing as well as negotiating the message(s). As a qualitative research, this study involves students as the respondents to be interviewed. Students' Intellectual diaries and essay drafts were also regarded as data. The students were assigned to write an essay on the topic of corruption. The data are interpreted in the way of the grounded theory. The results imply that the students are encouraged and driven to search for relevant knowledge, to recall related values and figures, and to construct the future awareness. These aspects summarize the potential of combining the language competence and literacy in the classroom activities.
\end{abstract}

Key words: Jeremiad approach, essay, literacy, competence 
Maru, M.G., Dukut, E.M., \& Liando, N.. Beyond Essay Structure: Compe- 283 tence and Literacy

\begin{abstract}
Abstrak: Makalah ini bertujuan membagikan pembentukan kompetensi mahasiswa dan kesadaran literasi dalam pengajaran penulisan esai dengan menggunakan pendekatan jeremiad, yang juga disebut pendekatan T - ex dalam kelas Bahasa Inggris sebagai Bahasa asing. Pendekatan ini menyarankan tiga aspek yakni, pertama, eksplanasi teks yang mengharuskan identifikasi dan presentasi suatu isu atau topik yang menantang dalam sebuah teks. Langkah selanjutnya, eksaminasi teks atau pemeriksaan mendalam atas aspek - aspek yan terkait dengan situasi dalam teks yang dapat dilihat sebagai solusi atau isu yang dibahas dengan merujuk pada pengetahuan, teknologi, nilai nilai sosial budaya, nilai sejarah, moral dan tokoh - tokoh panutan. Langkah ketiga atau terakhir dari pendekatan jeremiad adalah ekpektasi dalam teks yang menganjurkan makna prakmatis teks yaitu harapan akan perubahan sebagai hasil yang diperoleh dari pengetahuan yang diperoleh dilangkah kedua diatas, dan menyerukannya sebagai antisipasi masa depan. Setiap langkah ini bergantung pada kemampuan bahasa sebab bahasa didudukan sebagai alat menyusun, mengenal, dan menegosiasikan pesan atau makna. Sebagai studi kualitatif, penelitian ini melibatkan mahasiswa sebagai responden yang diwawancarai secara mendalam. Catatan harian dan draft esai mahasiswa juga dimanfaatkan sebagai sumber data. Dalam studi ini, responden diberi tugas menulis esai tentang korupsi. Data dianalisa dengan cara penelitian Grounded theory. Hasil penelitian mengungkapkan bahwa dengan menerapkan pendekatan jeremiad atau $T$ - ex dalam penulisan esai, mahasiswa didorong dan dituntun 1) penelusuran pengetahuan yang relevan, 2) menggali nilai dan figure - figure teladan, 3) merekonstruksi kesadaran akan masa depan. Temuan ini menyiratkan peran kontribusi pendekatan jeremiad atas pembentukan kompetensi dan kesadaran literasi dalam kelas bahasa inggris sebagai bahasa asing.
\end{abstract}

Kata kunci: Penulisan esai, pendekatan Jeremiad, kompetensi, kesadaran literasi, grounded theory

\title{
INTRODUCTION
}

Essay writing has always been a challenge for college students. Most of the assignments are required to be submitted in the form of essay. In that sense, Bacha (2002) synthesized that writing in the academic community is "paramount; a student cannot be successful without a certain level of academic writing proficiency" (p.15). It places an essay writing as one of the instrument for assessing students' competence in the academic world (Maru, 2016). The production of the essay is regarded to be the signal for students' ability to 
process knowledge and share it through language expressions. This assumes to involve two crucial aspects in the body of knowledge that is the reflection of process and product. Teachers may have the opportunities to frame students' needed feedbacks in the level of writing process, and to assess students' competence in the product part. Hence, there is commonly an intensive call for college students to engage with essay writing in terms of communicating complex information and idea to academic world and general audience (Welsh et al., 2017; Jandciu, Stewart, Stoodley, Birol, Han, \& Fox, 2015). It may serve as evaluation instrument for teachers and idea dissemination for students. As an argumentative writing, essay further can be used to measure not only the writing performance but also critical thinking skill (Indah, 2017; Rahim et al., 2008)

However, essay writing is not easy. Some learners even see it as a difficult language skill (Ardriyati and Hartono, 2014). The assignment in the form of essay remains "a constant complaint" (Silva, 2001) for students in any level especially in the context of English as second language or foreign language. Since "being a bit different from speaking skills in terms of the demand for the accuracy, essay writing demands comprehensive ways in the sense of the grammatical construction, the choice of the words and the punctuation use as well as the potential of analytical ability (Maru, 2016)". This suggests that the quality of an essay relies upon the linguistics competence for the reason of expression accuracy and the knowledge acquisition for the purpose of the content complexity and comprehensiveness. An essay summarizes students' knowledge as it comes from analytical ability and critical thinking, and language competence as it involves the proper use of language in its idea elaboration. That means that the challenge of essay writing lies in developing of language competence and enriching content knowledge. The lack of the competence and knowledge define the source of students' problem in producing an essay. Unsuccessful writing, according to Ardriyati and Hartono (2017), is due to "student may not know how to structure and sequence ideas with logical consistency, and how to use linguistic creativity, and how to write a text that shows coherence". Some students sometimes are trapped in focusing only on following the structure, yet ignoring the quality of the shared idea. Some merely emphasize on the content with incoherent structure.

In line with such tendency, this study intends to share the implication of jeremiad approach in essay writing in terms of proposing a learning breakthrough to develop students' language competence particularly for English learners and knowledge which is viewed as the reflection of students' critical thinking that later shape their literacy. This reasoning gains its advocacy 
Maru, M.G., Dukut, E.M., \& Liando, N.. Beyond Essay Structure: Compe- 285 tence and Literacy

relating to current challenge in Indonesian education that is in search for critical thinker (Indah, 2017; Emilia, 2010) in solving national problem such as corruption, radicalism and terrorism as well as anti-pluralism. Moreover, referring to the more challenging and competitive world today, critical thinking may contribute to equip students' basic literacy (reading, writing, arithmetic) with reasoning which is crucial for facing the complexity of present economic, social and cultural life. Therefore, this study takes essay writing as the focus to explore the implication of the Jeremiad approach in terms of detecting the shaping of students' literacy as a reflection of critical thinking and language competence.

The implementation of the jeremiad approach was in fact a part of the study supported by the scheme of the competence grant of the directorate of Research and community Outreach of the Ministry of Research and Higher Education, Indonesia. It was carried out as the academic and scientific response toward the phenomena that, in English language education, "the backdrop of global change has made teaching greatly complex, requiring alternative approaches of envisioning, innovating, and negotiating multiple pedagogical methods for new generations of students" (Bui, 2016; Darling Hammond, 2009; Hellot \& O'Laoire, 2011). In Indonesia, the new curriculum of 2013 prescribed the need of text-based learning in order to achieve three main components of learning outcome namely knowledge, skill and attitude (Maru, 2014). Further, English learning is attached with the competences built out of the materials which emphasize on the use of English as a tool of communication for expressing ideas and knowledge, the habit of reading, understanding, summarizing and reproducing a passage, and the habit of composing a text and the awareness to its rules (Kemendikbud, 2013). Such global and national circumstances characterize the grounds for the conduction of the study as whole.

The Jeremiad approach, which is so-called T-ex approach, is the newly proposed learning approach in the English as a foreign language class. Being rooted in the American rhetoric tradition, the jeremiad turns to be potential approach for language learning and text analysis. The emphasis of this study upon the contribution of the jeremiad approach to the making of competence and literacy was intended to define the application and implication of the approach in the area of language learning. Therefore, it took the case of teaching essay writing for students as it leads to an alternative for teaching writing skill particularly academic writing. 
286 Celt: A Journal of Culture, English Language Teaching \& Literature, Volume 18, Number 2, December 2018, pp. 282 - 296

\section{METHOD}

This study was undertaken at the English Education department in a University in North Sulawesi, Indonesia where students are commonly taught to structure their essays into conventional structure; introduction, body, and conclusion but faced by the high demand to develop literacy as well. Employing a qualitative research design, this study involved 26 students of the advance writing class who voluntarily agreed to take part in the study. They were considered as the subjects. The subjects responded to open recruitment to participate in this research.

The students were interviewed in natural setting. The students were asked to respond to the main question; what was your experience with the implementation of the jeremiad approach in essay writing and how it influenced your competence and literacy awareness. This study obtained the data in the forms of words taken from the students' commentaries to the given questions and its elaboration, and notes as well. The notes were part of their intellectual diaries in every meeting. The intellectual diary was part of weekly assignment. It contained the students' perception, feeling, and experience of every class meeting. Thus, it constitutes students' self-report of their own progress. Their essays were also regarded to be complimentary data. The essays were those of the first assignments to the last essay as the final product of the implementation of the approach.

The students were assigned to write an essay with the given topic namely the corruption issue. The essays were viewed to be final after having series of feedback in order to be in line with the frame of the jeremiad approach. All of the data were then coded in the frame of Thorberg' the informed Grounded Theory prescribing "a product of a research process as well as to the research process itself, in which both the process and the product have been thoroughly grounded in data by Grounded Theory methods while being informed by existing research literature and theoretical frameworks" (2012, p. 8). This implies that the data both obtained from the process and product were analyzed and interpreted in the way of open, axial and selective coding.

\section{DISCUSSION}

Essay writing mostly falls into the act of following the structure of introduction, body and conclusion. Students are encouraged to follow the given structure from which teachers design a test for the reason of providing 
Maru, M.G., Dukut, E.M., \& Liando, N.. Beyond Essay Structure: Compe- 287 tence and Literacy

"feedback during the process of acquiring writing proficiency and of assigning a grade or score that indicate the level of the written product" (Bacha, 2002). That implies that the goal of the essay writing seems to be narrowed down into technical matters with some linguistics rubric. Students view an essay as response toward a certain frame of paragraphs.

Meeting a well-planned structure of an essay has to be followed by the interpretation and analysis on certain issue or given focus giving. Hence essays are viewed as the combination of the skill of presentation and the exploration of language use. In developing and supporting an argument, students experience the challenge of putting ideas into a topic and learn to make it reasonable and acceptable with an appropriate language expression. It may occur through different strategies for prewriting, drafting and rewriting as well as revising. In other words, a good essay goes beyond the format or structure (Maru, 2016). It has to provide an insight mirroring the mastery of knowledge on a given topic or discipline. The success in writing in essay leads to the success in academic assessment and dissemination. Teachers apparently pay less attention in advising students how to put their ideas and transfer their knowledge down on paper in the form of an essay.

\section{A. The essay writing using Jeremiad approach}

Jeremiad Approach prescribes broader scope of an essay structure than that of traditional structure. As it is so-called T-Ex approach, it promotes three phases of teaching which emphasize upon the stages such as text explanation, text examination, and text expectation. (Maru, 2014), the T-ex approach suggests that an essay must be commenced with the explanation step which concerns with the identification or presentation of an issue or problem and its possible cause(s) as it is adapted from the idea of the lamentation of the present in jeremiad rhetoric (Elliot, 2002, Maru, 2013), and be followed by the examination step that relates to the attempt to offer solutions to the problem which refers to the tendency to gain inspiration and reference to the values, figure, historical events, philosophy and even religious teachings. It is concluded by the expectation which reflects the demands for renewal after addressing the solution for the issue of topic. It is a calling for the betterment or attitudinal changes in the future. Within this study, the jeremiad approach or T-ex approach is implemented in the following practices;

1. The explanation

At this stage, the classroom activity was addressed to start of addressing the given topic for students' essay, in this case corruption. The topic was 
288 Celt: A Journal of Culture, English Language Teaching \& Literature, Volume 18, Number 2, December 2018, pp. 282 - 296

chosen due to the flourish of the corruption nowadays. In fact, other issue such as radicalism, anti- pluralism, drug abuse and violence can serve as given topics. Teacher in the interaction with students built up the context of the topic. The teacher encouraged short class discussions on the issue of corruption including its background and related aspects. The familiarity and understanding of the given topic served to be the first activity to be done before beginning writing the essay.

Here, teachers may suggest the questions of what, why, when, who, and how as triggers to write. The information of what was happening contextually, what problem was faced both values/norms and textual, and what was the cause as well as the commentary (lamentation) on it. Thus, the essay would bring the points of the jeremiad that is the attempt to give the meaning to the situation faced by the society and the identification of its cause(s) (Maru, 2013).

These activities surely underline the communicative and inferential functions of the learnt language, in this case, English. The assignment was then given. Writing an essay begins with this frame of thought. The paragraph and essay structure remained applicable yet it was added with the requirement to elaborate not only the definition of the given issue or topic but also to detect the cause and its context as well. This means that students begin to recall their knowledge and transfer it with their language competence. Despite it was individual assignment but the students were also helped by the idea and insights obtained during the class opening discussion.

\section{The examination}

The basic proposition for this stage derives from the dogma in the second structure of a jeremiad which urges the discussion of the issue has to reveal the needs to reconcile the past with the present situation for the possible resolution. The past is reclaimed as the model for the attempt to solve the present perils. The past values are evoked to bring the enlightenment to face the decline of the present society. The values could be in the form of knowledge of the spirits, perspectives, attitudes and even moments or event of the past as well as the religious and cultural precepts that may inspire the revelation of the solution for the ongoing problems (Maru, 2014; Elliot, 2002). Such formulas were suggested to be the content of students' essay structure. 
Maru, M.G., Dukut, E.M., \& Liando, N.. Beyond Essay Structure: Compe- 289 tence and Literacy

Students made their own effort to discover references, knowledge, past lessons, history records, sublime values and attitudes, readings, and expressions of the great figures or founders, heroic deeds and events, and verses of holy books as well as the lessons from their environment or other disciplines. It defined the deep examination of the issue. The essay was extended to provide solution for the discussed topic. Therefore, students realized that the body of the essay is more than just elaboration and description of the topic. It goes beyond that perspective. The body of the essay mirrored students' stock of knowledge of figures, dogmas, values and norms, culture, law, and social practices. Further, it expounds.

\section{The expectation}

Having presenting the solution, the essay was attached to the purpose of the call for renewal constitutes as jeremiad usually did (Murphy, 2009, p.9; Maru, 2013). Here, the essay seemed to be pragmatic in its message and conclusion. It prescribed the need to voice and to inspire a particular attitude or change. Thus, conclusion of the essay does not only summarize the topic but also engage readers with response and change. The essay, after elaborating the corruption issues with its causes and showing the lessons of the past and figures to learn.

The students had the opportunity to state their stance and expectation. When an essay is accomplished in this pattern, it is regarded to be Jeremiadiac essay. It delineated the awareness of what has been the crisis befalling upon the society, what brings it to happen and what had been taught by the past to overcome it as well as the question of what should be done in the future.

It is important to note that, in this process of essay writing, revision was essential since students got feedbacks either from the teacher or peers. The teacher viewed the completion of the assigned essay to be finished after having several revisions. Both oral and written corrective feedbacks bridged the aims at increasing the students' language competence, in one side, and knowledge on the other side. Written corrective feedback, in particular, can be more beneficial for students as learners have greater processing time to compare their output with the corrections they received (Manchón, 2011; Maru, 2017). Further, written corrective feedback is "a complex construct due to the multiple options available for correcting students' writing, as well as the different ways in which learners can respond to it" (Peres-Nunez, 2015; Maru, 
2017). The teacher had the chance to suggest necessary aspects in terms of the betterment of the essay; whether it is related to the language aspects or topic elaboration. The students were then led to experience the improvement in their linguistic knowledge and the comprehensive understanding of an issue as well as the personal development.

The application of the jeremiad or T-ex approach to help developing students' essay writing skill revealed the situation that students experience. By coding the interview results, diaries and essay drafts following the approach implementation, the writing of the Jeremiadic essay had given students the opportunity to explore their ideas on the given issue, and accelerate their capacity as language learners. Being assigned to write about the issue of corruption, students found themselves to be challenged by perfecting their works through the attempts that characterize two advantages of teaching essay writing using the jeremiad approach.

\section{B. The growth of critical literacy}

The demand of the essay in the frame of jeremiad approach has stimulated students to the habit of gaining knowledge from the sources outside the classroom. They were challenged to enrich their understanding of the topic background and scope in order to deal with the explanation phase. Their identification of the topic; the reason for its rise and the circumstances that surround it, colored the commencement of long and wide journey of reading and searching for the sources.

The other two phases urged similar requirements. The essay is not merely designed to meet the conventional criteria of introduction, body and conclusion but also indicated the need of having comprehensive understanding. Apparently, this embodied what is meant by literacy as the ability to access, comprehend, and use information intellectually. In other words, the essay writing created the habit of digging information related to certain topic and sharing through a composition. Bui (2016) synthesized that students have the potential to capture "the complexity of certain issues, identifying problems, offering solutions, and considering their own previous conceptualization" (p.249). These potentials could be practiced as long as they have enough stock of knowledge which is believed to be gained by reading a lot. In so doing, the literacy habit determines the quality of the essay written.

Students grew to realize that the process of writing particularly an essay requires more knowledge to chip-in. One of the respondents acknowledged, 
Maru, M.G., Dukut, E.M., \& Liando, N.. Beyond Essay Structure: Compe- 291 tence and Literacy

The feedbacks given to my essay in several meetings until my essay was considered being done really drove me to active searching of information from many sources both printed and online. It was not fun until i realized the joy of knowing many things related to my topic (student 7).

By the help of feedbacks, students shape their literacy awareness as they made the attempts to acquire information and ideas from multiple readings. This is, of course, followed by the ability to gather and select most relevant information for the subject matter. At this point, students develop and perform their heuristic intuition which is actually that of literacy awareness.

In writing their essay, students actually performed data collection and categorization for elaborating the topic which constitute the gain of knowledge and the meeting with critical thinking propensity. This implies that the implementation of the T-Ex approach in the essay writing engages students with the recalling and cultivating of knowledge based their own repertoire which is resulted from their reading habits. The literacy awareness got clear by the activity of writing itself. Since literacy does not solely relate to reading habit but also to the writing to share.

The T-Ex approach accustomed students to focus on elaborating the given issue. The complexity of topic was responded by the process of selecting of the most relevant knowledge. They searched for information, selected, categorized, interpreted and transferred it into their essay. It is obvious that at the moment the students saw themselves not as simply receiving an assignment of writing or receiving teachers' knowledge transfer but also exposing themselves to the core activities of learning as they enriched themselves with variety of literacy activities such as accessing information, doing readings and writing as well.

Being framed not only to explain and examine but also call for change, students were driven to combine all of the gathered information into detail knowledge of the issue. It was noted in following students' diary comment, "My resources were needed to be used to enrich my essay" (Student 24). This portrays a logical impact of following the thought of the jeremiad approach. When the students' literacy had been awakened, they created their own space "establish background knowledge and improved skills" (Bui, 2016). They would bring more diversity of perspectives to the topic. Their familiarity to the academic readings would shape the academic taste of their essay. Some of religious fondness tended to extend their topic to the attachment to the factors 
of religious dogmas. In other words, there is seemingly a mutual relationship between essay and the shaping of literacy. The need to gain a good essay in the perspective of jeremiad approach had made students to develop literacy awareness while literacy habit determined the quality of the essay. That means that the more students involve in essay writing, the more they develop their literacy awareness.

Moreover, the topic of the essay does not stand in vacuum. The elaboration of the topic both in terms of explaining and examination or expectation is not apart from context. Students began to focus on the corruption issue, for example. It was not zero contexts. The definition of 'corruption' itself may vary according to who writes the essay. One of the respondent pointed out,

The information then enables me to comprehend the topic or the given subject matter, the focus on the subject matter guides my search and broaden my knowledge on it, I get the substance of the matter, for example, once I just knew that corruption is not only about money (Student 3).

As their literacy developed, students were able to put the issue in a context and to recall other multiple perspectives. As the respondent constructed the corruption, it relies upon the previous knowledge obtained in the knowledge search process. It is literacy. Later, it emphasized that literacy awareness itself is "culturally embedded and socially constructed" (Lai, 2005). It means that students in the efforts to elaborate the given topic, in this case the issue of corruption, put the perspective on corruption on the basis of their closest environment and of their most familiar circumstance.

The students construct values and norms for the topic in accordance with those of the society and culture in which they live. Their sociocultural background selected the ingredients of their literacy to share in their writing. The references that had been encountered during the journey of finding relevant sources for the given topic would be naturally in line with their sociocultural tendency.

It can be drawn a proposition that although essay in the frame of jeremiad approach proposes the structure of thought to write, it goes beyond that tendency; it develops the critical literacy as students selected the sources, accessed and processed, and later shared them in the essay. Within this context, students' own interpretations of the supporting material were dominant in the essay. They tended to evolve a coherent view on the topic 
Maru, M.G., Dukut, E.M., \& Liando, N.. Beyond Essay Structure: Compe- 293 tence and Literacy

from their reading, which determined their use of evidence and the organization of their essay. "They were focused on making meaning, and developing an individual view of the topic based on a firm empirical foundation" (Hounsell, 1987, p. 1997). Such practice defines the shaping of the literacy awareness among the students and characterizes the impact of using the jeremiad approach in essay writing in ELT class. However, it implicitly uncovers that the scope and width of students' literacy undeniably depend upon the availability and comprehensiveness of the resources provided by institutions both printed and digital ones. The body of knowledge obtained by the literature for the attempt to organize the ideas and to make meaning of it designates more helps required for students that go beyond merely feedback and teaching materials.

\section{The acquiring of language competence}

Essay is designed to be read and understood. It is not written for vacuum. It carries message in all its possible forms. At this point, the jeremiad approach makes its way by emphasizing upon the pragmatic aspect of essay writing. An essay shall express identification of problem, solution, and call for change. It leads to the need for the clarity the message which further portrays the clarity of language expression and other linguistics features used. As a basically student-center approach, the jeremiad approach assigns the exploration of the language competence in negotiating meaning and message, not to ignore the role of the comprehensive written corrective feedbacks during the writing process and the product assessment. Such process helps students to recall their language knowledge. The students picture such experience in the following citation,

Every time I submitted my essay (before final submission), teacher gave notes on the mistakes that I made. The feedback came in the form of underlined words and phrases or construction. The jeremiadic structure required more references and language knowledge. Suggestions related to some linguistic knowledge helped me to recognize my mistakes and drove me to learn, it was tiring but a bit fun, and moreover we knew that others did the same. (Student 24)

It is inferred from the citation that in fact the jeremiad approach for an essay includes the corrective feedbacks. It shapes students' efforts to improve their language knowledge not solely on grammatical construction but also on its pragmatic sense. The process of the writing seemed to serve as the self- 
assessment opportunities for students. They were diagnosed and informed about their mistakes from which they gained competence. The ability to choose for proper expressions and extend the use of sentence or clause as well as combined multi-types of conjunction or markers equipped students for conveying ideas and setting the arguments. In other words, the attempts to state writers' standpoint, to argue using examples, or to conclude and to define the subject matter recall students' need for higher competence of language. It can be stated that the challenge of establishing point of view on the given topic, making the subject matter understood, and crafting the voice to be heard energize the process of language exposure and acquisition in the essay writing. The students may transfer the feedbacks into the advantage of overcoming the language hindrances. The challenge of language forms and structures in negotiating meaning and conveying message flourishes the accumulation of language knowledge.

Yet, considering the jeremiad approach underlines the independence of students as learners to develop their essay, it is important for teachers to follow the writing process as an alert observant who cares for students' individual creativity and needs; seeing them as the signs for progress. Giving feedbacks and reminding the focus of the essay frames the duty of the teachers of engaging the language and content. That conceptualizes that the improvement of language competence, in this case, has to be in purpose of working the points of the jeremiad structure. Hence, the language competence grows as the critical thinking on the given topic grows. It works simultaneously; the notions are elaborated and explored, at the same time, the language competence is in need to be enhanced for the totality of the Jeremiadic essay.

\section{CONCLUSION}

In terms of jeremiad approach, students' essay reflects the intellectual development as they experience dialectic interaction with references and knowledge for accomplishing the content frame of the approach. It implies the literacy process working within the process of the completion of the essay. The pragmatic nuance of the stages in the essay writing drives students to pursue more knowledge in which they insistently develop their critical thinking in managing and analyzing baseline for the arguments and expectation.

Similarly, the approach generates the need for language competence in terms of enabling students to convey their ideas. The language improvement may occur since following the structure is not merely the aim of writing 
Maru, M.G., Dukut, E.M., \& Liando, N.. Beyond Essay Structure: Compe- 295 tence and Literacy

jeremiadic essay but also the sequence of intellectual capacity in presenting problem identification and solution presentation and the expectation for renewal or change that requires the sequence of well-structured expressions and contructions. Yet, these blessings beyond structure are challenged by the availability of resources and students' tendency to view an essay as an academic assignment, not critical thinking ability.

\section{REFERENCES}

Antoro, B., \& Muldian, W. (2015). Buku saku gerakan literasi sekolah Ditjen Dikdasmen Kemendikbud [Pocket book for the school literacy movement Directorate General of Primary and Secondary Education Ministry of Education and Culture].

Ardriyati, W., \& Hartono, H. (2004). Contextual coherence in recount essay. Celt: A Journal of Culture, English Language Teaching $\mathcal{E}$ Literature, 4(1), 1927.

Bacha, N. N. (2002). Testing Writing. In English teaching forum (Vol. 40). US Department of State.

Bui, T. (2016). Critical Literacy in an EFL Classroom in Vietnam: Agentive Empowerment, Ideological and Language Transformations. The Journal of AsiaTEFL, 13(4), 247-261.

Crowley, J. (2015). Graphic novels in the school library: using graphic novels to encourage reluctant readers and improve literacy. The School Librarian, 63(3), 140.

Emilia, E. (2010). Teaching writing: Developing critical learners. Bandung, Indonesia: Rizqi Press.

Ganji, M. (2009). Teacher-correction, peer-correction and self-correction: Their impacts on Iranian students' IELTS essay writing performance. The journal of Asia TEFL, 6(1), 117-139.

Herbert, J. C. (2003). English Prime as an Instructional tool in writing classes. In English Teaching Forum, 41(3), 26-31.

Hounsell, D. (1987). Essay writing and the quality of feedback in Richardson. 
296 Celt: A Journal of Culture, English Language Teaching \& Literature, Volume 18, Number 2, December 2018, pp. 282 - 296

Hounsell, D. (1997). Understanding teaching and teaching for understanding. The experience of learning, 2.

Indah, R. N. (2017). Critical thinking, writing performance and topic familiarity of Indonesian EFL learners. Journal of Language Teaching and Research, 8(2), 229-236.

Jandciu, E., Stewart, J. J., Stoodley, R., Birol, G., Han, A., \& Fox, J. A. (2015). Bridging the Gap: Embedding Communication Courses in the Science Undergraduate Curriculum. Journal on Excellence in College Teaching, 26(4), 103-123.

Kuo, J. M. (2014). Critical literacy in the EFL classroom: Evolving multiple perspectives through learning tasks. The Journal of AsiaTEFL, 11(4), 109. 138.

Lai, S. J. (2005). English Literacy Learning as a Socially Situated Practice. The Journal of AsiaTEFL, 2(4), 41-65.

Lai, S. J. (2004). Learning English Literacy as an Aspect of Social Practice. The Journal of AsiaTEFL, 1(1), 131-147.

Maru, M. G. (2013). Jeremiad Frames in Reagan's inaugural addresses. Jurnal Humaniora, 25(1), 25-37.

Maru, M. G. (2014). Experimenting Jeremiadic Approach as an Alternative for TEFL in Meeting the Demand of the 2013 Curriculum. In Proceeding. 61th TEFLIN International Conference.

Maru, M. G., Ratu, D. M., \& Dukut, E. M. (2018). The Use of the T-Ex Approach in Indonesian EFL Essay Writing: Feedbacks and Knowledge Exploration. International Journal of Engineering $\mathcal{E}$ Technology, 7(3.25), 386-390, http://dx.doi.org/10.14419/ijet.v7i3.25.17602

Thornberg, R. (2012). Informed grounded theory. Scandinavian Journal of Educational Research, 56(3), 243-259.

Warburton, N. (2006). The basics of essay writing. London: Routledge. 